\title{
Overcoming barriers and thresholds - signaling of oligomeric $A \beta$ through the prion protein to Fyn
}

Hansen Wang ${ }^{1}$, Carl He Ren ${ }^{1,2}$, C Geeth Gunawardana ${ }^{1}$ and Gerold Schmitt-Ulms ${ }^{1,2^{*}}$

\begin{abstract}
Evidence has been mounting for an involvement of the prion protein (PrP) in a molecular pathway assumed to play a critical role in the etiology of Alzheimer disease. A currently popular model sees oligomeric amyloid $\beta$ (oA $\beta$ ) peptides bind directly to PrP to emanate a signal that causes activation of the cytoplasmic tyrosine kinase Fyn, an essential player in a cascade of events that ultimately leads to NMDA receptor-mediated excitotoxicity and hyperphosphorylation of tau. The model does not reveal, however, how extracellular binding of oA $\beta$ to PrP is communicated across the plasma membrane barrier to affect activation of Fyn. A scenario whereby PrP may adapt a transmembrane topology to affect Fyn activation in the absence of additional partners is currently not supported by evidence. A survey of known candidate PrP interactors leads to a small number of molecules that are known to acquire a transmembrane topology and understood to contribute to Fyn activation. Because multiple signaling pathways converge onto Fyn, a realistic model needs to take into account a reality of Fyn acting as a hub that integrates signals from multiple inhibitory and activating effectors. To clarify the role of PrP in oA excitotoxicity, future studies may need to incorporate experimental designs that can probe the contributions of Fyn modulator pathways and rely on analogous readouts, rather than threshold effects, known to underlie excitotoxic signaling.
\end{abstract}

Keywords: Alzheimer disease, Amyloid $\beta$ peptide, Fyn, Prion protein, Tau, Excitotoxicity

\section{Review}

The concomitant accumulation of extracellular aggregates of $A \beta$ peptides and intracellular deposits of the tau protein is a neuropathological hallmark of Alzheimer disease (AD). The details of the molecular biology that connects these AD signature aggregation events are not understood. A currently popular model posits that exposure of cells to oligomeric forms of the amyloid $\beta$ peptide (oA $\beta$ ) triggers a cascade of events that causes N-methyl-D-aspartate (NMDA) receptor-mediated excitotoxicity and intracellular deposition of hyperphosphorylated tau (reviewed in [1]).

To date, arguably the most instructive data on this topic may have emerged from the study of selected

\footnotetext{
* Correspondence: g.schmittulms@utoronto.ca

${ }^{1}$ Tanz Centre for Research in Neurodegenerative Diseases, University of

Toronto, Tanz Neuroscience Building, 6 Queen's Park Crescent West, Toronto, Ontario M5S 3H2, Canada

${ }^{2}$ Department of Laboratory Medicine and Pathobiology, University of Toronto, Toronto, Ontario M5S1A8, Canada
}

mouse models. As early as in 1998 it was reported that ablation of Fyn, a non-receptor tyrosine kinase of the larger family of Src family kinases (SFKs), diminishes $\mathrm{oA} \beta$ toxicity [2]. Around the same time it was shown that SFKs can bind to the $\mathrm{N}$-terminal projection domain of tau [3]. First proposed in 2002, it is now widely accepted that oA $\beta$ excitotoxicity also depends on the availability and proper cellular targeting of tau [4,5]. A recent study connected some of the dots by showing that a tau construct engineered to retain the projection domain but lacking the microtubule binding domain misdirected Fyn and prevented oA $\beta$ toxicity $[6,7]$.

Any model of cellular oA $\beta$ toxicity needs to explain how extracellular oA $\beta$ communicates its presence into the cell. The process can be broken into two main steps: (1) binding of oA $\beta$ to the cellular membrane; and (2) signaling across the cellular membrane when oA $\beta$ binding has taken place. A large number of theories have been put forward that hypothesize on the nature of the first

\section{Biomed Central}


step and the cellular binding partner involved (see [8,9] for recent reviews). Without a question, amongst the many oA $\beta$ candidate receptors proposed, the prion protein $(\operatorname{PrP})$ has of late received the most attention. This may in part be due to the fact that the role of $\operatorname{PrP}$ as a candidate oA $\beta$ interactor emerged from a hypothesisfree screen, as opposed to conceptually more limited approaches that suggested involvement of many other receptor candidates. At this time, the cumulative binding data available for the oA $\beta-\operatorname{PrP}$ interaction are the most validated and robust for any oA $\beta$ candidate receptor [10-15]. When combined with the aforementioned model a refined scenario emerged according to which oA $\beta$ binds to PrP which, in turn, causes activation of Fyn following its delivery to the inner face of the plasma membrane, a step that appears to require tau (Figure 1). However, an ongoing controversy surrounds the significance of oA $\beta$ binding to $\operatorname{PrP}$ and, more specifically, the question whether this interaction is responsible for downstream neurotoxicity and impairment of long-term potentiation [12,16,17], an electrophysiological surrogate of learning and memory formation. Possible reasons for data discrepancies have been proposed before $[1,18,19]$

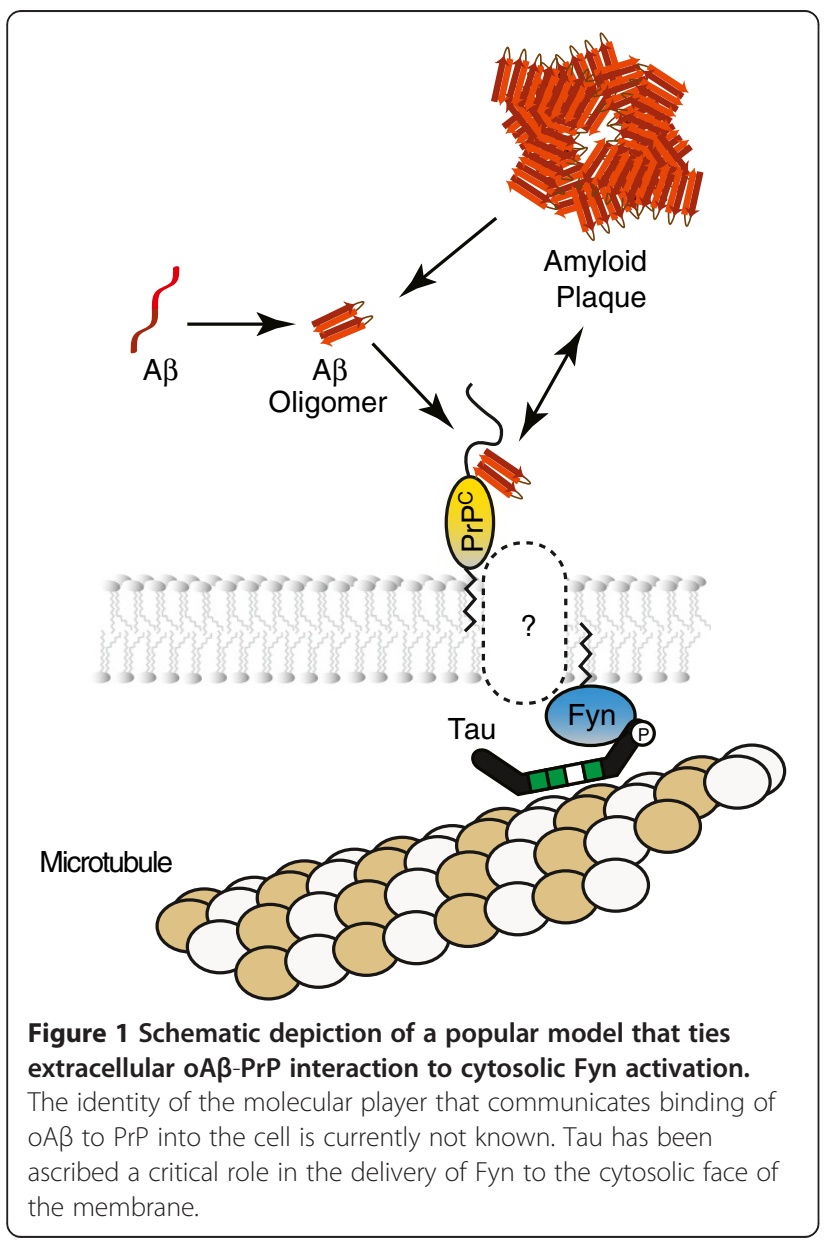

and will only be touched in the second half of this article where we highlight aspects that may not have been adequately considered in previous reports.

The focus of this perspective will be on a related question: How is it that $\operatorname{PrP}$, a glycosylphosphatidylinositol (GPI) anchored molecule, tethered to the outer face of the membrane, can activate an intracellular SFK? The need to answer this pressing question has also been noted by others [10], and has led to a situation where several authors of recent papers indicated this knowledge gap in schematic models either with conspicuous question marks or by omitting labels for the corresponding molecular entity altogether (e.g., schematic drawings in $[20-22])$.

\section{Overcoming barriers - signaling from PrP to Fyn}

A natural place to begin the search for the missing link that ties PrP to Fyn activation is to state the properties a candidate needs to fulfill to serve in this role, namely (i) the ability to bind to PrP; (ii) the existence of a membrane-spanning topology; and (iii) a known role as an activator of SFKs. Although a large number of candidate PrP interactors have been described [23,24], to our knowledge only neural cell adhesion molecules (NCAMs) [25,26], integrin/non-integrin laminin receptors [27], and caveolin-1 [28,29] meet all three of the aforementioned criteria and shall be described in more detail in the following paragraphs. A scenario whereby a PrP-dependent signal may traverse the plasma membrane independent of other transmembrane proteins-if the presence of oA $\beta$ induces a well-known but rare transmembrane topology in $\mathrm{PrP}$-will also not be discussed here because, to date, no evidence exists that ties these transmembrane forms of PrP to Fyn activation [19]. Naturally, the decision to limit discussions to PrP interactors with a known Fyn connection is not intended to deny the possible existence of such a connection for other proteins that have been proposed to bind to PrP. The reader will appreciate though that the omission of this operational restriction would have forced a more cursory description of many PrP interactors at the expense of the more focussed perspective that was the aim of this review.

NCAMs are members of the immunoglobulin (Ig) superfamily of cell adhesion molecules [30] and are in humans coded on chromosomes 11 (NCAM1) and 21 (NCAM2). Whereas NCAM1 is widely expressed throughout the human brain, NCAM2 is primarily observed in the olfactory bulb. Additional complexity of NCAM expression profiles emerges from alternative splicing and gives rise to both GPI-anchored (p120NCAM1) and transmembrane forms (p140-NCAM1 and p180-NCAM1) with short cytoplasmic tails. The ectodomain of NCAM1 or NCAM2 comprises five N- 
terminal Ig-like domains and two membrane-adjacent fibronectin-type 3 (FN3) domains. Given their shared mode of GPI-dependent membrane attachment, it is not surprising to find p120-NCAM1 in proximity of PrP, and even p140-NCAM1 has been shown to be recruited to raft-like domains upon acylation of its cytoplasmic domain [31]. NCAM1 was initially shown to co-immunoprecipitate with $\operatorname{PrP}$ following in vivo crosslinking of mouse Neuroblastoma cells (Neuro2a) and the direct interaction was shown to depend on a protein-protein interface that mapped to $\beta$-strands $C$ and $\mathrm{CO}$ within the two consecutive FN3 modules of NCAM1 and the N-terminus and helix A (residues 144154) within PrP [26]. Subsequent large-scale interactome studies confirmed not only that NCAM1 is a prominent molecular neighbor of $\operatorname{PrP}$ in both cultured neuronal cells and the brain $[27,32]$ but further established that the interaction may recruit NCAM1 into raft-like domains and trigger a signal that leads to activation of Fyn [25], a finding that had partly been foreshadowed by data which indicated that NCAM1 acts in certain experimental paradigms upstream of Fyn [33]. A hint at the mechanism by which NCAM1-lacking an SFK activation domain of its own-may activate Fyn then emerged from studies that documented a dependency of NCAM1mediated neuritic outgrowth on receptor-type tyrosineprotein phosphatase $\alpha$ (PTPRA), also known as RPTP $\alpha$ [34]. The finding complemented prior data which had documented that PTPRA can activate SFKs by removing their inhibitory C-terminal tyrosine phosphorylation $[35,36]$ and was operative in transmembrane Fyn activation emanating from contactins [35] or integrins [37]. PTPRA may itself get activated in this context by phosphorylation at two serine acceptor sites (S180/204) $[38,39]$. One scenario suggests PTPRA is phosphorylated by protein kinase $\mathrm{C}$ in this manner once this kinase has been recruited through $\operatorname{PrP}^{\mathrm{C}}$-dependent clustering of NCAM1 [40] (Figure 2A).

Non-integrin- and integrin-based laminin interactions: $\mathrm{PrP}^{\mathrm{C}}$ has repeatedly been shown to interact with ribosomal protein SA (RPSA), also known as the $67 \mathrm{kDa}$ laminin receptor [41], a cellular non-integrin receptor of laminin. The link to the extracellular matrix protein laminin was further strengthened when a quantitative interactome analysis revealed $\operatorname{PrP}$ to co-purify with VLA-6 [27], a heterodimeric $\alpha 6 \beta 1$ integrin complex also known to mediate cellular attachment to laminin (Figure 2B). Integrins represent a large family of transmembrane receptors with well-established roles in mediating cellular contacts with extracellular matrices. Mammalian genomes code for $18 \alpha$ and $8 \beta$ subunits of integrins that assemble into more than 24 known functional $\alpha / \beta$ heterodimers with specialized roles in extracellular matrix recognition [42]. In addition to the $\alpha 6 \beta 1$ complex, PrP was shown to also co-enrich with $\alpha \mathrm{V}$, an integrin subunit with a role in vitronectin recognition [27]. Although no direct connection of RPSA to SFK has been established, in addition to having been independently identified as laminin and PrP interactors, RPSA and integrins are known to interact with each other [43-45] and integrins are well-known to signal through SFKs. The exact mechanisms by which integrin heterodimers, lacking conspicuous intracellular signaling domains, activate SFKs are less well understood. It is, however, known that extracellular matrix interactions of integrin complexes trigger conformational rearrangements within the integrin heterodimers that expose cytosolic epitopes which, in turn, may sequester signaling factors. A more indirect mechanism of $\alpha 6 \beta 1$ integrin signaling may rely on its association with L1. Similar to NCAM, L1 is a cell adhesion molecule of the immunoglobulin superfamily that was shown to co-enrich with $\operatorname{PrP}$ [27]. The existence of macromolecular complexes comprising integrins and L1 is no controversial issue [46] and has been shown to rely on the affinity of integrins toward an RGD-amino acid motif within the Ig-like domain 6 in L1 [47]. However, the precise mechanism by which the complex activates Fyn or other SFKs is still somewhat unclear. Some authors have suggested activation may be based on the aforementioned tyrosine phosphatase PTPRA $[48,49]$ (as in Figure 2A).

Caveolins are small membrane-embedded proteins that assemble into clathrin-like lattices and give shape to so-called caveolae, 50-100 nanometer diameter membrane domains enriched in cholesterol and sphingolipids [50]. Caveolae play a role in diverse biological activities, including receptor-independent endocytosis, transcytosis and the docking of viruses and toxins, and also serve as integration hubs for cell signaling [50]. Of the three known caveolins (caveolin-1, -2 and -3) the caveolin-1 gene product has been implicated in $\operatorname{PrP}^{\mathrm{C}}$-dependent signaling to Fyn. Early work indicated that a cytosolic membrane-proximal region of caveolin-1 (residues 82100) can bind Src or Fyn, leading to suppression of tyrosine kinase activity [51]. Subsequent reports described that antibody-mediated crosslinking of $\operatorname{PrP}^{\mathrm{C}}$ in a cell model of neuronal differentiation (1C11) [28] or in a hypothalamic neuronal cell line (GN11) [52] can lead to caveolin-1 dependent Fyn activation. A more recent study conducted with the PC12 cell model suggested yet another twist to the role of caveolin-1 in $\operatorname{PrP}^{\mathrm{C}}$-dependent Fyn signaling. The authors proposed PrP-mediated crosslinking may rely on integrins for signal transmission across the membrane but that a phosphoepitope generated on caveolin-1 serves in this process as a docking site to recruit Src kinase and inactivate Fyn [53] (Figure 2C).

Needless to say, the short list of molecules discussed in the preceding paragraphs may not yet contain the 


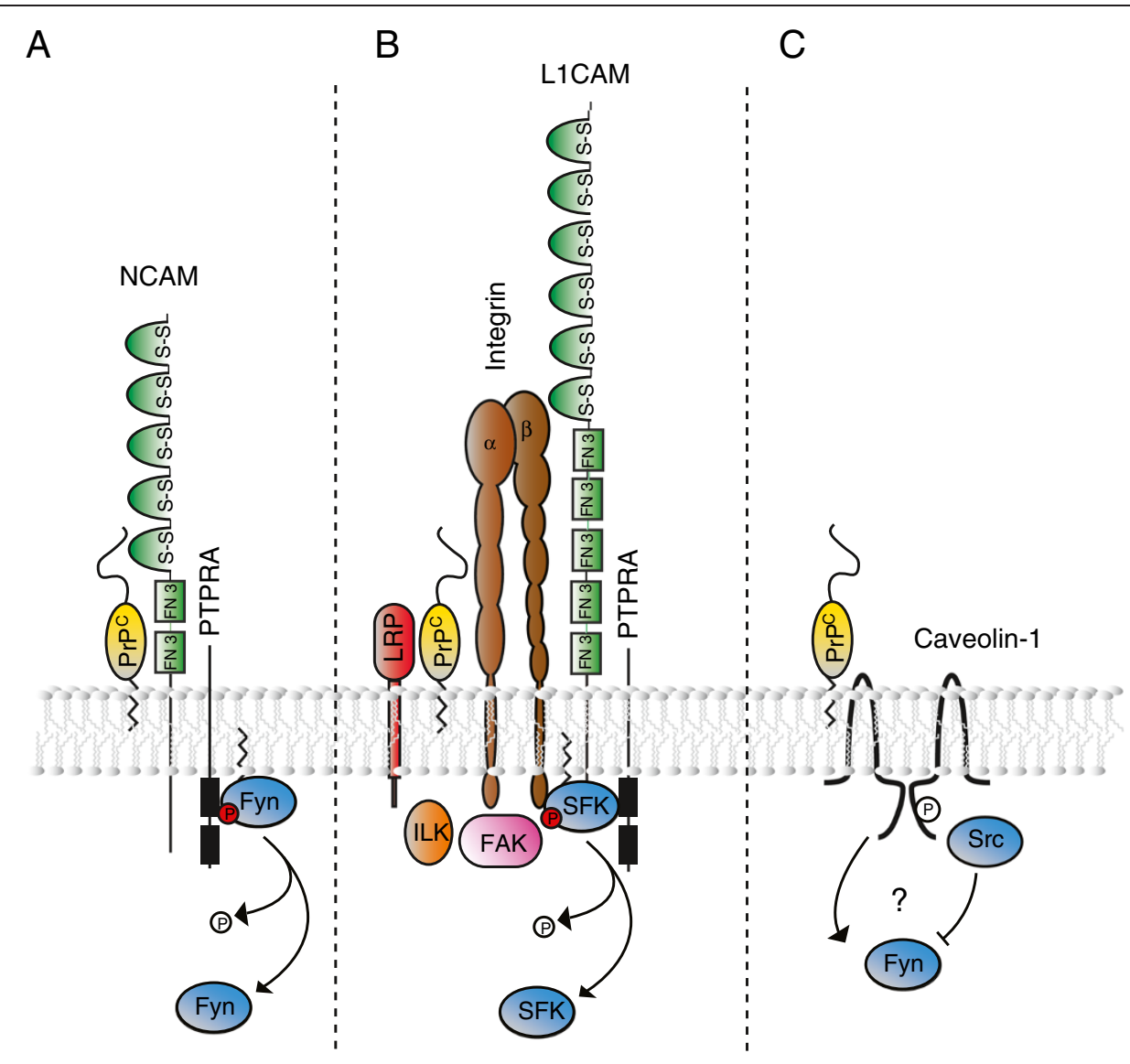

Figure 2 Possible scenarios and molecular players that may be operative in overcoming the membrane barrier required for PrP-to-Fyn signaling. (A) PrP may recruit NCAM into raft domains causing its association with PTPRA, a known activator of Fyn. (B) PrP may influence cellular attachment to laminin by interacting with multiple molecules known to play key roles in this cell-to-extracellular matrix interaction. A sub complex of integrins and L1 is known to activate SFKs, again possibly through interaction with PTPRA. (C) PrP may modulate activity of Fyn by interacting with Caveolin-1. The consequence of this interaction with regard to Fyn activity status is currently unclear or may not be consistent across experimental paradigms.

missing link responsible for oA $\beta$-mediated signaling from $\operatorname{PrP}$ to Fyn. Therefore, efforts to validate the role of these candidates need to be pursued in parallel to unbiased searches for novel interactors of PrP in its oA $\beta$-bound state based on hypothesis-free discovery platforms (e.g., affinity capture followed by mass spectrometry or mammalian two-hybrid system derivatives). Conclusive evidence that a given $\operatorname{PrP}$ interactor represents the missing link will not come easy as the field is lacking robust experimental paradigms. Even some of the most widely used experimental setups that recapitulate oA $\beta$-dependent tau hyperphosphorylation, i.e., the treatment of rodent primary neurons or hippocampal slice cultures with $\mathrm{oA} \beta$, are far from trivial and relatively refractory to manipulations. A first meaningful step, however, would be to show that the knockdown of a missing link candidate protein in these paradigms reduces oA $\beta$-dependent Fyn activation. These studies should be complemented with efforts to map the precise protein-protein interfaces that mediate binding of a candidate missing link to PrP and Fyn. Once this hurdle has been taken, candidate genes will need to be validated in rodent $\mathrm{AD}$ models, an objective made easier with recent advances in gene targeting strategies [54]. Aside from the challenge to identify a suitable AD model, these experiments could, however, be confounded by developmental or compensatory systems biology. To be able to correlate the knockout of a candidate gene with a reduction in oA $\beta$-dependent Fyn activation experimental approaches need to be either sensitive (if analyses are undertaken on brain tissue homogenates) or, preferably, offer single-cell resolution, because the molecular phenotype is likely to manifest in only a subset of cells.

\section{Overcoming thresholds - molecular networks, signaling hubs and cellular programs}

So far in this article protein-protein interactions that $\operatorname{PrP}^{\mathrm{C}}$ engages in have been described as if they existed in 
isolation or followed a strictly linear and sequential signaling logic. Although useful at a certain level, this approach does not do justice to a reality of a highly intricate cell biology governed by molecular networks, convergence and branching of signaling pathways and highly coordinated cellular programs than can choreograph the molecular biology of a large number of proteins concomitantly $[55,56]$. In the second part of this review an attempt is made to capture some of this complexity.

Although many proteins that $\operatorname{PrP}^{C}$ is surrounded by in the brain have been identified by large-scale $\operatorname{PrP}^{\mathrm{C}}$-centric interactome studies in mice [32,57], little is known about the authentic molecular neighborhood of this protein in a given brain cell relevant for AD. In the absence of this information, data from a quantitative $\mathrm{PrP}^{\mathrm{C}}$ interactome analysis in mouse neuroblastoma cells may offer the next best glimpse into the molecular environment of $\operatorname{PrP}^{\mathrm{C}}$ in a specific cell type [58]. According to this study $\operatorname{PrP}^{\mathrm{C}}$ resides sufficiently close to a few dozen different proteins to facilitate its covalent intermolecular crosslinking to them. As expected for a protein that is inserted into the plasma membrane by a glycosylphosphatidylinositol anchor, the PrP interactome is dominated by ER- and Golgi-resident proteins, as well as other membrane proteins. Of note, a body of literature suggests that a substantial proportion of $\operatorname{PrP}^{\mathrm{C}}$ resides within cells in membrane (lipid) rafts [59,60], detergent-resistant membrane domains rich in cholesterol and sphingolipids, and it has been proposed that this localization of $\operatorname{PrP}^{\mathrm{C}}$ is critical for its ability to mediate $\mathrm{oA} \beta$ toxicity [61]. Although the organizing principles that drive the composition of membrane rafts are still a matter of debate [62], it is likely that the molecular neighborhood of $\mathrm{PrP}^{\mathrm{C}}$ within these raft domains is not only governed by $\operatorname{PrP}^{\mathrm{C}}$-lipid interactions but also by the relative affinity of $\mathrm{PrP}^{\mathrm{C}}$ towards other raft-resident proteins [63]. On the basis of these considerations it may not surprise that a majority of the aforementioned $\operatorname{PrP}^{\mathrm{C}}$ interactors (e.g., NCAM [31], the laminin recepetor precursor [64], integrins [65] and caveolin-1 [28]) have also been localized-at least transiently-in membrane rafts or in the aforementioned caveolae, a specialized subset of membrane rafts. Consequently, signals emanating from $\operatorname{PrP}^{\mathrm{C}}$ and leading to Fyn activation are unlikely to solely rely on the interaction of $\operatorname{PrP}^{\mathrm{C}}$ with just one type of binding partner but, instead, when circumstances are permissive (see below), may involve, to varying degrees, and in parallel, multiple of the signaling scenarios outlined above (Figure 2).

A first indication that concerted action of multiple PrP molecules might be needed for Fyn activation provided the aforementioned antibody-mediated PrP crosslinking data in the $1 \mathrm{C} 11$ neuronal differentiation cell model
[28]. A more general role of receptor clustering in Fyn activation came to the fore when it was subsequently shown that several other receptors could similarly only activate Fyn when clustered and associated with membrane rafts $[40,66,67]$. Whereas there is general agreement that only oA $\beta$, not $\mathrm{mA} \beta$, binds to $\operatorname{PrP}$ $[12,13,29,68]$, less clear is whether oligomeric forms of $A \beta$ illicit neurotoxicity chiefly on account of their multi-valency and, thus, ability to promote Fyn activation through clustering of PrP.

Because Fyn itself acts as a molecular hub on which signals from multiple pathways converge, a realistic evaluation of its activation state needs to consider additional inputs known to modulate Fyn activity. Thus, the signaling outcome of oA $\beta$ binding to $\operatorname{PrP}^{\mathrm{C}}$ will also be impacted by the status of STEP2, Shp2 and a few other kinases/ phosphatases that, taken together, influence the activity level of Fyn (see Figure 3). When viewed in this light, a number of seemingly disconnected observations may begin to make sense. It has, for example, been reported that antibodies specific for the $\beta 1$ subunit of integrins can block oA $\beta$-mediated toxicity in primary neuronal cultures [69]. In light of the signal hub role of Fyn and an absence of evidence that $\mathrm{oA} \beta$ can bind to integrins, this observation could reflect an influence of integrin biology on Fynrelated signaling (see Figure 2B). Similarly, inhibitors of amylin receptors have repeatedly been shown to prevent oA $\beta$-dependent toxicity but there is no compelling data that oA $\beta$ can bind to amylin receptors [70,71]. Amylin receptors, however, are known to initiate a signaling cascade that utilizes the second messenger cAMP to activate protein kinase A (PKA) [72-74], which in turn would be predicted to alter the activity of STEP2 and, thereby, modulate the activation status of Fyn [75].

A similar integration of inhibitory and activating signals likely occurs at multiple points of convergence of pathways involved in NMDA receptor-mediated excitotoxicity, including an increasingly understood but highly intricate biology that underlies the modulation of expression levels, subcellular positioning and posttranslational activation of NMDA receptors themselves $[75,80]$. For example, the ability of PKA to modulate NMDA receptor activation may not only operate by impacting Fyn activity through regulation of STEP2 but may, in addition, influence Fyndependent activation of NMDA channels by controlling its association with Rack1. To this end, it has been demonstrated that PKA phosphorylation of Rack1 causes its translocation, thereby freeing cytosolic phospho-acceptor sites within the channel's NR2B subunit from a steric hindrance to Fyn phosphorylation (reviewed in [75]). Thus, the restricted focus on Fyn signal integration in this review does not reflect a view that Fyn is the only, or even the most important, signal integration hub on pathway to excitotoxic signaling in AD. 


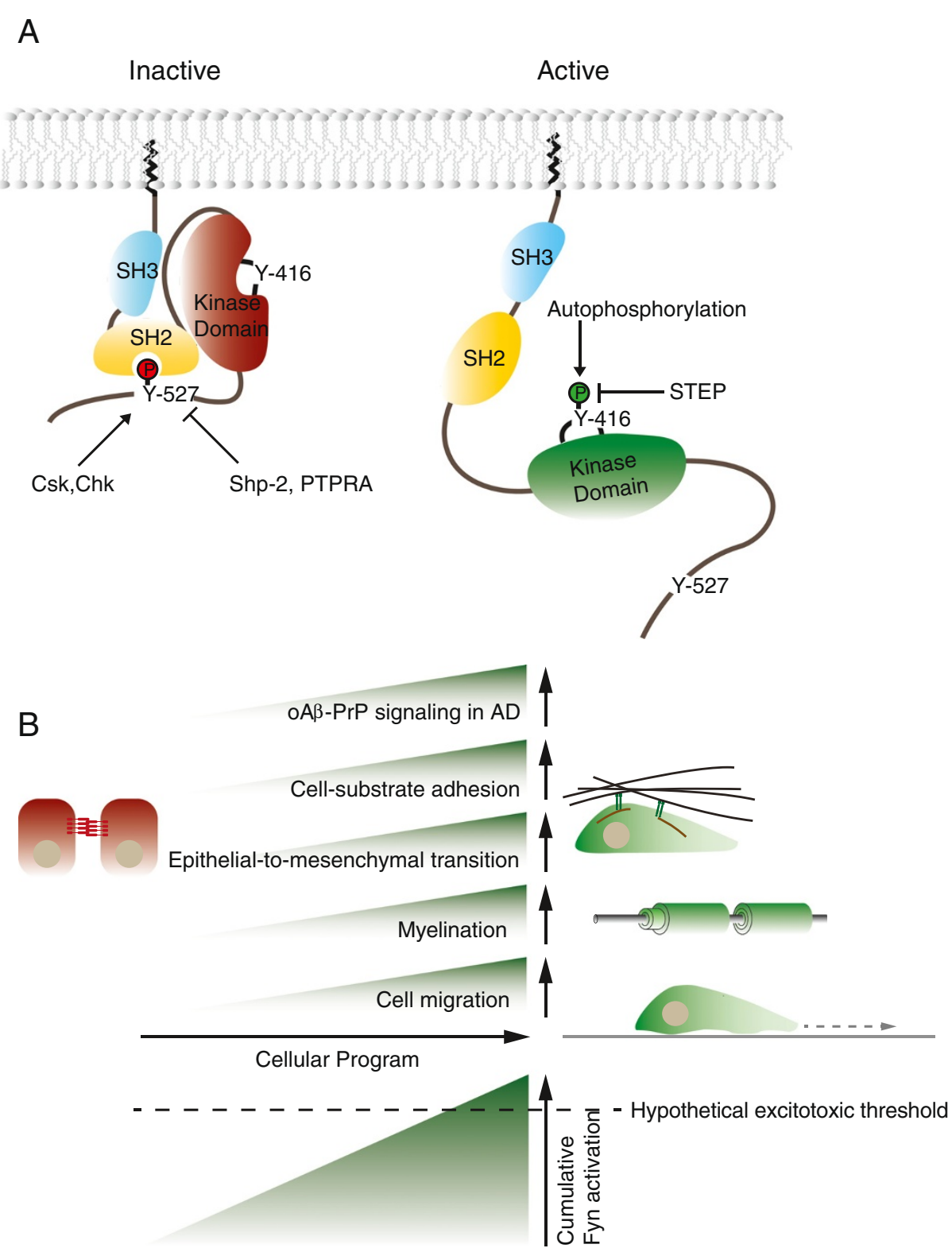

Figure 3 Fyn's role as a signal integration hub involved in a number of cellular programs need to be taken into account when assessing role of $\operatorname{PrP}$ in oA $\beta$ excitotoxicity paradigms. (A) Fyn belongs to the family of non-receptor-type protein tyrosine kinases referred to as Src family kinases (SFKS), of which five members (Src, Fyn, Yes, Lck and Lyn) are known to be expressed in the human brain, and Fyn and Src are of primary interest in the context reviewed here [76]. All SFKs share a modular domain organization composed of a Src homology 2 (SH2) domain sandwiched between an N-terminal Src homology $3(\mathrm{SH} 3)$ domain and a C-terminal tyrosine kinase domain. The inactive state of these kinases can be stabilized by an intramolecular interaction that forms when the SH2 domain binds to a C-terminal tyrosine-phosphate (Y527). Full activation requires dephosphorylation of this inhibitory phosphate and autophosphorylation within the activation loop in the tyrosine kinase domain. Various tyrosine kinases and phosphatases have been shown to control occupancy of these critical acceptor sites. Thus, SFK activity is negatively regulated through Y527 phosphorylation by C-terminal Src Kinase (CSK) or CSK homologous kinase (CHK) and through dephosphorylation of Y416 by striatal-enriched tyrosine phosphatase (STEP) [77]. Positive effectors of SFK activity are the receptor-type protein tyrosine phosphatases Shp-2 [78,79] and PTPRA [35,36] that were shown to selectively remove the inhibitory Y527 phosphate. (B) Cellular programs known to modulate Fyn activation levels. Upon oA reflective of the cell type, its developmental status and the programs executed in the cell.

Given that Fyn is considered to exist in cells predominantly in an inactive state, the question arises as to which broader cellular programs cause its activation.
The kinase has been linked to diverse biological functions. Whereas early work on Fyn emphasized possible neurological and immunological functions, interest has 
shifted toward other roles that include its involvement in neurite elongation in oligodendrocytes [81] and neurons [34], myelination [82,83], and the cellular reprogramming that can lead to epithelial-to-mesenchymal transition $[84,85]$ or cancer $[86,87]$. Interestingly, the molecular biology underlying a subset of these cellular programs is surprisingly similar. Commonalities are a reliance on signaling through membrane lipid raft domains, morphogenetic rearrangements that depend on cell-to-substrate adhesion and even the shared involvement of a strikingly overlapping set of molecular players. It is, for example, increasingly being understood that the cellular program which drives myelination depends on an intricate molecular network that includes GPIanchored molecules, a subset of integrins, L1 and Fyn $[82,83,88,89]$. Similarly, the transient interactions that a motile cell forms toward its substrate or that a growing neurite engages in as it is probing its environment have been known for some time to make use of signaling through rafts and strongly depend on Fyn activation $[25,33,81]$. Finally, it is emerging that many of the same proteins are also involved in the execution of epithelialto-mesenchymal transitions, cellular programs relevant for both normal development during ontogenesis and abnormal motility of cells seen during invasive stages of cancers $[84,86,87]$. It is not known at this time if the molecular overlaps of these cellular programs also offer a starting point for understanding why $\operatorname{PrP}$ deficiency leads to a myelin maintenance defect affecting peripheral nerves in mice [90] but causes a defect in epithelial-to -mesenchymal transition during the early developmental gastrula stage in zebrafish [91].

Returning to the main theme of this article, the question arises if a cell that is executing one of the cellular programs which involve Fyn activation is more susceptible to oA $\beta$ toxicity. Similarly, can testable hypotheses be derived from the aforementioned considerations that may bridge the seemingly irreconcilable positions of the two camps of scientists who either insist PrP to be critical or not necessary at all for oA $\beta$-mediated neurotoxicity? It is noteworthy that the apparent controversy surrounding the involvement of $\operatorname{PrP}^{\mathrm{C}}$ in mediating oA $\beta$ toxicity is based on models that measure threshold effects, i.e., the excitotoxic activation of NMDA receptors in similar but non-identical experimental paradigms. In such a scenario, small differences in Fyn activation levels can manifest as dramatic differences in outcome. A productive path forward to reconcile the apparent contradictions in observations, therefore, might be to base future analyses on read-outs that are by their nature analogous and quantifiable, e.g., the ratio of levels of activated Fyn to total Fyn. A first step in this direction might be to establish the relative contributions converging pathways exert on the cumulative overall Fyn activation levels. In other words, does the oA $\beta$ effect on PrP represent a dominant or minor Fyn activation pathway? Future attempts to push back oA $\beta$-mediated neurotoxicity may be futile if therapeutic interventions concentrate on only one of multiple pathways that converge on Fyn. Unless the overall level of Fyn activation is reduced, its excitotoxic threshold may be overcome through cellular changes that manifest with age or altered metabolism, or an acute imbalance of a given Fynactivation pathway based on inflammation or injury.

\section{Conclusions}

The ongoing debate surrounding the proposed involvement of $\operatorname{PrP}$ in a central signaling pathway thought to connect oA $\beta$ exposure of cells to Fyn activation has repolarized the $A D$ research field. Insights into the molecular mechanism by which $\operatorname{PrP}$ may communicate oA $\beta$ binding into the cell are urgently needed. This review distilled from a broad literature on PrP protein-protein interactions NCAM, integrins and, possibly, caveolin-1 as molecules worth investigating for a possible involvement in this step. Validation efforts for these proteins could be pursued in parallel to research aimed at revealing additional candidates. A revised model should also consider the role clustering of PrP may play in oA $\beta$-mediated Fyn activation. Finally, a reality of Fyn operating as a signal integration hub demands experimental designs that can more fully capture the level of Fyn activation and suggests attention should also be paid to alternative pathways and cellular programs Fyn participates in.

\section{Abbreviations}

AD: Alzheimer disease; GPI: glycosylphosphatidylinositol; NCAM: neural cell adhesion molecule; NMDA: N-methyl-D-aspartate; oA $\beta$ : oligomeric amyloid $\beta$; $\operatorname{PrP}^{C}$ : cellular prion protein; PTPRA: receptor-type tyrosine-protein phosphatase a; RPSA: ribosomal protein SA; SFK: Src family kinase.

\section{Competing interests}

All authors declare no competing interests.

\section{Authors' contributions}

GS conceptualized and drafted a first version of the manuscript. All authors contributed to the interpretation of data, the design of illustrations and the revising of the manuscript. All authors read and approved the final manuscript.

\section{Authors' information}

Dr. Hansen Wang is a Senior Postdoctoral Researcher at the University of Toronto. He is currently investigating signaling downstream of oA $\mathrm{B}$. Carl He Ren is a Graduate student at the University of Toronto. He is studying the physiological role of the prion protein. Dr. Geeth Gunawardana is a Postdoctoral Research Fellow at the University of Toronto. His research focuses on the role of the tau protein in oA $\beta$-dependent excitotoxic signaling. Dr. Gerold Schmitt-Ulms trained in the laboratory of Dr. Stanley Prusiner at the University of California, San Francisco, before joining the Tanz Centre for Research in Neurodegenerative Diseases (Tanz CRND), University of Toronto, in 2003. He is an Associate Professor and Graduate Faculty of the Department of Laboratory Medicine \& Pathology (LM\&P). Dr. Schmitt-Ulms' work contributes to two strands of research at the interface of proteomics and neurodegenerative disease research: the development of strategies for the study of protein interactions and the application of these strategies to dissect the early etiology of Alzheimer disease and prion diseases. 


\section{Acknowledgements}

Work on this project was funded through support by the Canadian institute for health research, PrioNet Canada and the W. Garfield Weston foundation.

Received: 17 May 2013 Accepted: 9 July 2013

Published: 16 July 2013

\section{References}

1. Ittner LM, Gotz J: Amyloid-beta and tau-a toxic pas de deux in Alzheimer's disease. Nat Rev Neurosci 2011, 12:65-72.

2. Lambert MP, Barlow AK, Chromy BA, Edwards C, Freed R, Liosatos M, Morgan TE, Rozovsky I, Trommer B, Viola KL, et al: Diffusible, nonfibrillar ligands derived from Abeta1-42 are potent central nervous system neurotoxins. Proc Natl Acad Sci 1998, 95:6448-6453.

3. Lee G, Newman ST, Gard DL, Band H, Panchamoorthy G: Tau interacts with src-family non-receptor tyrosine kinases. J Cell Sci 1998, 111(Pt 21):3167-3177.

4. Rapoport M, Dawson HN, Binder LI, Vitek MP, Ferreira A: Tau is essential to beta -amyloid-induced neurotoxicity. Proc Natl Acad Sci 2002, 99:6364-6369

5. Roberson ED, Halabisky B, Yoo JW, Yao J, Chin J, Yan F, Wu T, Hamto P, Devidze N, Yu GQ, et al: Amyloid-beta/Fyn-induced synaptic, network, and cognitive impairments depend on tau levels in multiple mouse models of Alzheimer's disease. J Neurosci 2011, 31:700-711.

6. Ittner LM, Ke YD, Delerue F, Bi M, Gladbach A, van ersel J, Wolfing H, Chieng BC, Christie MJ, Napier IA, et al: Dendritic function of tau mediates amyloid-beta toxicity in Alzheimer's disease mouse models. Cell 2010, 142:387-397.

7. Haass C, Mandelkow E: Fyn-tau-amyloid: a toxic triad. Cell 2010, 142:356-358.

8. Patel AN, Jhamandas JH: Neuronal receptors as targets for the action of amyloid-beta protein (Abeta) in the brain. Expert Rev Mol Med 2012, 14:e2.

9. Dinamarca MC, Rios JA, Inestrosa NC: Postsynaptic receptors for amyloidbeta oligomers as mediators of neuronal damage in Alzheimer's disease. Front Physiol 2012, 3:464.

10. Um JW, Nygaard HB, Heiss JK, Kostylev MA, Stagi M, Vortmeyer A, Wisniewski T, Gunther EC, Strittmatter SM: Alzheimer amyloid-beta oligomer bound to postsynaptic prion protein activates Fyn to impair neurons. Nat Neurosci 2012, 15:1227-1235.

11. Barry AE, Klyubin I, Mc Donald JM, Mably AJ, Farrell MA, Scott M, Walsh DM, Rowan MJ: Alzheimer's disease brain-derived amyloid-beta-mediated inhibition of LTP in vivo is prevented by immunotargeting cellular prion protein. J Neurosci 2011, 31:7259-7263.

12. Calella AM, Farinelli M, Nuvolone M, Mirante O, Moos R, Falsig J, Mansuy IM, Aguzzi A: Prion protein and Abeta-related synaptic toxicity impairment. EMBO Mol Med 2010, 2:306-314.

13. Chen S, Yadav SP, Surewicz WK: Interaction between human prion protein and amyloid-beta (Abeta) oligomers: role OF N-terminal residues. J Biol Chem 2010, 285:26377-26383.

14. Kudo W, Lee HP, Zou WQ, Wang X, Perry G, Zhu X, Smith MA, Petersen RB, Lee HG: Cellular prion protein is essential for oligomeric amyloid-beta -induced neuronal cell death. Hum Mol Genet 2011, 21:1138-1144.

15. Zou WQ, Xiao X, Yuan J, Puoti G, Fujioka H, Wang X, Richardson S, Zhou X, Zou R, Li S, et al: Amyloid-beta42 interacts mainly with insoluble prion protein in the Alzheimer brain. J Biol Chem 2011, 286:15095-15105.

16. Balducci C, Beeg M, Stravalaci M, Bastone A, Sclip A, Biasini E, Tapella L, Colombo L, Manzoni C, Borsello T, et al: Synthetic amyloid-beta oligomers impair long-term memory independently of cellular prion protein. Proc Natl Acad Sci 2010, 107:2295-2300.

17. Cisse M, Sanchez PE, Kim DH, Ho K, Yu GQ, Mucke L: Ablation of cellular prion protein does not ameliorate abnormal neural network activity or cognitive dysfunction in the J20 line of human amyloid precursor protein transgenic mice. J Neurosci 2011, 31:10427-10431.

18. Benilova I, De Strooper B: Prion protein in Alzheimer's pathogenesis: a hot and controversial issue. EMBO Mol Med 2010, 2:289-290.

19. Biasini E, Turnbaugh JA, Unterberger U, Harris DA: Prion protein at the crossroads of physiology and disease. Trends Neurosci 2012, 35:92-103.

20. Petit-Paitel A, Menard B, Guyon A, Beringue V, Nahon JL, Zsurger N, Chabry $\mathrm{J}$ : Prion protein is a key determinant of alcohol sensitivity through the modulation of N-methyl-D-aspartate receptor (NMDAR) activity. PLoS One 2012, 7:e34691.
21. Morris M, Maeda S, Vossel K, Mucke L: The many faces of tau. Neuron 2011, 70:410-426

22. Cisse M, Mucke L: Alzheimer's Disease: a prion protein connection. Nature 2009, 457:1090-1091.

23. Aguzzi A, Baumann F, Bremer J: The Prion's elusive reason for being. Annu Rev Neurosci 2008, 31:439-477.

24. Sorgato MC, Peggion C, Bertoli A: Is, indeed, the prion protein a Harlequin servant of "many" masters? Prion 2009, 3:202-205.

25. Santuccione A, Sytnyk V, Leshchyns'ka I, Schachner M: Prion protein recruits its neuronal receptor NCAM to lipid rafts to activate p59fyn and to enhance neurite outgrowth. J Cell Biol 2005, 169:341-354.

26. Schmitt-Ulms G, Legname G, Baldwin MA, Ball HL, Bradon N, Bosque PJ, Crossin KL, Edelman GM, DeArmond SJ, Cohen FE, Prusiner SB: Binding of neural cell adhesion molecules (N-CAMs) to the cellular prion protein. J Mol Biol 2001, 314:1209-1225.

27. Watts JC, Huo H, Bai Y, Ehsani S, Jeon AH, Shi T, Daude N, Lau A, Young R, $\mathrm{Xu} \mathrm{L}$, et al: Interactome analyses identify ties of PrP and its mammalian paralogs to oligomannosidic $\mathrm{N}$-glycans and endoplasmic reticulumderived chaperones. PLoS Pathog 2009, 5:e1000608.

28. Mouillet-Richard S, Ermonval M, Chebassier C, Laplanche JL, Lehmann S, Launay JM, Kellermann O: Signal transduction through prion protein Science 2000, 289:1925-1928.

29. Larson M, Sherman MA, Amar F, Nuvolone M, Schneider JA, Bennett DA, Aguzzi A, Lesne SE: The Complex PrPc-Fyn couples human oligomeric abeta with pathological Tau changes in Alzheimer's disease. J Neurosci 2012, 32:16857-16871.

30. Maness PF, Schachner M: Neural recognition molecules of the immunoglobulin superfamily: signaling transducers of axon guidance and neuronal migration. Nat Neurosci 2007, 10:19-26.

31. Niethammer P, Delling M, Sytnyk V, Dityatev A, Fukami K, Schachner M: Cosignaling of NCAM via lipid rafts and the FGF receptor is required for neuritogenesis. J Cell Biol 2002, 157:521-532.

32. Schmitt-Ulms G, Hansen K, Liu J, Cowdrey C, Yang J, DeArmond SJ, Cohen FE, Prusiner SB, Baldwin MA: Time-controlled transcardiac perfusion crosslinking for the study of protein interactions in complex tissues. Nat Biotech 2004, 22:724-731.

33. Beggs HE, Soriano P, Maness PF: NCAM-dependent neurite outgrowth is inhibited in neurons from Fyn-minus mice. J Cell Biol 1994, 127:825-833.

34. Bodrikov V, Leshchyns'ka I, Sytnyk V, Overvoorde J, den Hertog J, Schachner M: RPTPalpha is essential for NCAM-mediated p59fyn activation and neurite elongation. J Cell Biol 2005, 168:127-139.

35. Zeng L, D'Alessandri L, Kalousek MB, Vaughan L, Pallen CJ: Protein tyrosine phosphatase alpha (PTPalpha) and contactin form a novel neuronal receptor complex linked to the intracellular tyrosine kinase fyn. J Cell Biol 1999, 147:707-714

36. Su J, Muranjan M, Sap J: Receptor protein tyrosine phosphatase alpha activates Src-family kinases and controls integrin-mediated responses in fibroblasts. Current biology : CB 1999, 9:505-511.

37. von Wichert G, Jiang G, Kostic A, De Vos K, Sap J, Sheetz MP: RPTP-alpha acts as a transducer of mechanical force on alphav/beta3-integrincytoskeleton linkages. J Cell Biol 2003, 161:143-153.

38. Tracy $S$, van der Geer P, Hunter T: The receptor-like protein-tyrosine phosphatase, RPTP alpha, is phosphorylated by protein kinase $\mathrm{C}$ on two serines close to the inner face of the plasma membrane. J Biol Chem 1995, 270:10587-10594.

39. Zheng XM, Resnick RJ, Shalloway D: Mitotic activation of protein-tyrosine phosphatase alpha and regulation of its Src-mediated transforming activity by its sites of protein kinase C phosphorylation. J Biol Chem 2002, 277:21922-21929.

40. Bodrikov V, Sytnyk V, Leshchyns'ka I, den Hertog J, Schachner M: NCAM induces CaMKIllalpha-mediated RPTPalpha phosphorylation to enhance its catalytic activity and neurite outgrowth. J Cell Biol 2008, 182:1185-1200.

41. Gauczynski S, Peyrin JM, Haik S, Leucht C, Hundt C, Rieger R, Krasemann S, Deslys JP, Dormont D, Lasmezas Cl, Weiss S: The 37-kDa/67-kDa laminin receptor acts as the cell-surface receptor for the cellular prion protein. EMBO J 2001, 20:5863-5875.

42. Campbell ID, Humphries MJ: Integrin structure, activation, and interactions. Cold Spring Harb Perspect Biol 2011, 3:1-14.

43. Magnifico A, Tagliabue E, Buto S, Ardini E, Castronovo V, Colnaghi Ml, Menard S: Peptide G, containing the binding site of the $67-\mathrm{kDa}$ laminin 
receptor, increases and stabilizes laminin binding to cancer cells. J Biol Chem 1996, 271:31179-31184.

44. Pellegrini R, Martignone S, Menard S, Colnaghi MI: Laminin receptor expression and function in small-cell lung carcinoma. Int J Cancer Suppl 1994, 8:116-120

45. Ardini E, Tagliabue E, Magnifico A, Buto S, Castronovo V, Colnaghi MI, Menard S: Co-regulation and physical association of the $67-\mathrm{kDa}$ monomeric laminin receptor and the alpha6beta4 integrin. J Biol Chem 1997, 272:2342-2345.

46. Ruppert M, Aigner S, Hubbe M, Yagita H, Altevogt P: The L1 adhesion molecule is a cellular ligand for VLA-5. J Cell Biol 1995, 131:1881-1891.

47. Felding-Habermann B, Silletti S, Mei F, Siu CH, Yip PM, Brooks PC, Cheresh DA, O'Toole TE, Ginsberg MH, Montgomery AM: A single immunoglobulinlike domain of the human neural cell adhesion molecule L1 supports adhesion by multiple vascular and platelet integrins. J Cell Biol 1997, 139:1567-1581.

48. Zeng L, Si X, Yu WP, Le HT, Ng KP, Teng RM, Ryan K, Wang DZ, Ponniah S, Pallen CJ: PTP alpha regulates integrin-stimulated FAK autophosphorylation and cytoskeletal rearrangement in cell spreading and migration. J Cell Biol 2003, 160:137-146.

49. Chen M, Chen SC, Pallen CJ: Integrin-induced tyrosine phosphorylation of protein-tyrosine phosphatase-alpha is required for cytoskeletal reorganization and cell migration. J Biol Chem 2006, 281:11972-11980.

50. Williams TM, Lisanti MP: The caveolin proteins. Genome Biol 2004, 5:214.

51. Li S, Couet J, Lisanti MP: Src tyrosine kinases, galpha subunits, and H-Ras share a common membrane-anchored scaffolding protein, caveolin. Caveolin binding negatively regulates the auto-activation of Src tyrosine kinases. J Biol Chem 1996, 271:29182-29190.

52. Toni M, Spisni E, Griffoni C, Santi S, Riccio M, Lenaz P, Tomasi V: Cellular prion protein and caveolin-1 interaction in a neuronal cell line precedes Fyn/Erk 1/2 signal transduction. J Biomed Biotechnol 2006, 2006:69469.

53. Pantera B, Bini C, Cirri P, Paoli P, Camici G, Manao G, Caselli A: PrPc activation induces neurite outgrowth and differentiation in PC12 cells: role for caveolin-1 in the signal transduction pathway. J Neurochem 2009, 110:194-207.

54. Wang $H$, Yang $H$, Shivalila CS, Dawlaty MM, Cheng AW, Zhang F, Jaenisch R: One-Step generation of mice carrying mutations in multiple genes by CRISPR/Cas-mediated genome engineering. Cell 2013, 153:910-918.

55. Zhang B: Integrated systems approach identifies genetic nodes and networks in late-onset Alzheimer's disease. Cell 2013, 153:707-720.

56. Lewitzky M, Simister PC, Feller SM: Beyond 'furballs' and 'dumpling soups' - towards a molecular architecture of signaling complexes and networks. FEBS Lett 2012, 586:2740-2750.

57. Rutishauser D, Mertz KD, Moos R, Brunner E, Rulicke T, Calella AM, Aguzzi A: The comprehensive native interactome of a fully functional tagged prion protein. PLoS One 2009, 4:e4446.

58. Bai $Y$, Markham $K$, Chen F, Weerasekera R, Watts J, Horne P, Wakutani $Y$, Bagshaw R, Mathews PM, Fraser PE, et al: The in vivo brain interactome of the amyloid precursor protein. Mol Cell Proteomics 2008, 7:15-34.

59. Borchelt DR, Rogers M, Stahl N, Telling G, Prusiner SB: Release of the cellular prion protein from cultured cells after loss of its glycoinositol phospholipid anchor. Glycobiology 1993, 3:319-329.

60. Naslavsky N, Stein R, Yanai A, Friedlander G, Taraboulos A: Characterization of detergent-insoluble complexes containing the cellular prion protein and its scrapie isoform. J Biol Chem 1997, 272:6324-6331.

61. Rushworth JV, Griffiths HH, Watt NT, Hooper NM: Prion protein-mediated toxicity of amyloid-beta oligomers requires lipid rafts and the transmembrane LRP1. J Biol Chem 2013, 288:8935-8951.

62. Leslie M: Mysteries of the cell. Do lipid rafts exist? Science 2011, 334:1046-1047.

63. Lingwood D, Simons K: Lipid rafts as a membrane-organizing principle. Science 2010, 327:46-50

64. Fujimura Y, Yamada K, Tachibana H: A lipid raft-associated $67 \mathrm{kDa}$ laminin receptor mediates suppressive effect of epigallocatechin-3-O-gallate on FcepsilonRI expression. Biochem Biophys Res Commun 2005, 336:674-681.

65. van Zanten TS, Cambi A, Koopman M, Joosten B, Figdor CG, Garcia-Parajo MF: Hotspots of GPI-anchored proteins and integrin nanoclusters function as nucleation sites for cell adhesion. Proc Natl Acad Sci USA 2009, 106:18557-18562.

66. Rabinowich H, Manciulea M, Herberman RB, Whiteside TL: Beta1 integrin-mediated activation of focal adhesion kinase and its association with Fyn and Zap-70 in human NK cells. J Immuno/ 1996, 157:3860-3868

67. Ramseger $R$, White $R$, Kroger S: Transmembrane form agrin-induced process formation requires lipid rafts and the activation of Fyn and MAPK. J Biol Chem 2009, 284:7697-7705

68. Lauren J, Gimbel DA, Nygaard HB, Gilbert JW, Strittmatter SM: Cellular prion protein mediates impairment of synaptic plasticity by amyloid-beta oligomers. Nature 2009, 457:1128-1132.

69. Wright S, Malinin NL, Powell KA, Yednock T, Rydel RE, Griswold-Prenner I: Alpha2beta1 and alphaVbeta1 integrin signaling pathways mediate amyloid-beta-induced neurotoxicity. Neurobiol Aging 2007, 28:226-237.

70. Alier K, Ma L, Yang J, Westaway D, Jhamandas JH: Abeta inhibition of ionic conductance in mouse basal forebrain neurons is dependent upon the cellular prion protein PrPC. J Neurosci 2011, 31:16292-16297.

71. Jhamandas JH, Harris KH, Cho C, Fu W, MacTavish D: Human amylin actions on rat cholinergic basal forebrain neurons: antagonism of betaamyloid effects. J Neurophysiol 2003, 89:2923-2930.

72. Kuwasako K, Shimekake Y, Masuda M, Nakahara K, Yoshida T, Kitaura M, Kitamura K, Eto T, Sakata T: Visualization of the calcitonin receptor-like receptor and its receptor activity-modifying proteins during internalization and recycling. J Biol Chem 2000, 275:29602-29609.

73. Fu W, Ruangkittisakul A, MacTavish D, Shi JY, Ballanyi K, Jhamandas JH: Amyloid beta (Abeta) peptide directly activates amylin-3 receptor subtype by triggering multiple intracellular signaling pathways. $J$ Biol Chem 2012, 287:18820-18830.

74. Hay DL, Christopoulos G, Christopoulos A, Poyner DR, Sexton PM: Pharmacological discrimination of calcitonin receptor: receptor activitymodifying protein complexes. Mol Pharmacol 2005, 67:1655-1665.

75. Trepanier $\mathrm{CH}$, Jackson MF, MacDonald JF: Regulation of NMDA receptors by the tyrosine kinase Fyn. FEBS J 2012, 279:12-19.

76. Ohnishi H, Murata Y, Okazawa H, Matozaki T: Src family kinases: modulators of neurotransmitter receptor function and behavior. Trends Neurosci 2011, 34:629-637.

77. Nguyen TH, Liu J, Lombroso PJ: Striatal enriched phosphatase 61 dephosphorylates Fyn at phosphotyrosine 420. J Biol Chem 2002, 277:24274-24279.

78. Zhang SQ, Yang W, Kontaridis MI, Bivona TG, Wen G, Araki T, Luo J, Thompson JA, Schraven BL, Philips MR, Neel BG: Shp2 regulates SRC family kinase activity and Ras/Erk activation by controlling Csk recruitment. Mol Cell 2004, 13:341-355.

79. Peng ZY, Cartwright CA: Regulation of the Src tyrosine kinase and Syp tyrosine phosphatase by their cellular association. Oncogene 1995, 11:1955-1962.

80. Groveman BR, Feng S, Fang XQ, Pflueger M, Lin SX, Bienkiewicz EA, Yu X: The regulation of $\mathrm{N}$-methyl-D-aspartate receptors by Src kinase. FEBS J 2012, 279:20-28.

81. Klein C, Kramer EM, Cardine AM, Schraven B, Brandt R, Trotter J: Process outgrowth of oligodendrocytes is promoted by interaction of fyn kinase with the cytoskeletal protein tau. J Neurosci 2002, 22:698-707.

82. Sperber BR, Boyle-Walsh EA, Engleka MJ, Gadue P, Peterson AC, Stein PL, Scherer SS, MCMorris FA: A unique role for Fyn in CNS myelination. J Neurosci 2001, 21:2039-2047.

83. Laursen LS, Chan CW, ffrench-Constant C: An integrin-contactin complex regulates CNS myelination by differential Fyn phosphorylation. J Neurosci 2009, 29:9174-9185.

84. Kim AN, Jeon WK, Lim KH, Lee HY, Kim WJ, Kim BC: Fyn mediates transforming growth factor-beta1-induced down-regulation of E-cadherin in human A549 lung cancer cells. Biochem Biophys Res Commun 2011, 407:181-184.

85. Smyth D, Leung G, Fernando M, McKay DM: Reduced surface expression of epithelial E-cadherin evoked by interferon-gamma is Fyn kinasedependent. PLoS One 2012, 7:e38441.

86. Li X, Yang Y, Hu Y, Dang D, Regezi J, Schmidt BL, Atakilit A, Chen B, Ellis D, Ramos DM: Alphavbeta6-Fyn signaling promotes oral cancer progression. J Biol Chem 2003, 278:41646-41653.

87. Saito YD, Jensen AR, Salgia R, Posadas EM: Fyn: a novel molecular target in cancer. Cancer 2010, 116:1629-1637.

88. Barbin G, Aigrot MS, Charles P, Foucher A, Grumet M, Schachner M, Zalc B, Lubetzki C: Axonal cell-adhesion molecule L1 in CNS myelination. Neuron Glia Biol 2004, 1:65-72

89. Kramer EM, Klein C, Koch T, Boytinck M, Trotter J: Compartmentation of Fyn kinase with glycosylphosphatidylinositol-anchored molecules in 
oligodendrocytes facilitates kinase activation during myelination. J Biol Chem 1999, 274:29042-29049.

90. Bremer J, Baumann F, Tiberi C, Wessig C, Fischer H, Schwarz P, Steele AD, Toyka KV, Nave KA, Weis J, Aguzzi A: Axonal prion protein is required for peripheral myelin maintenance. Nat Neurosci 2010, 13:310-318.

91. Malaga-Trillo E, Solis GP, Schrock Y, Geiss C, Luncz L, Thomanetz V, Stuermer CA: Regulation of embryonic cell adhesion by the prion protein. PLOS Biol 2009, 7:e55.

doi:10.1186/1750-1326-8-24

Cite this article as: Wang et al:: Overcoming barriers and thresholds signaling of oligomeric $A \beta$ through the prion protein to Fyn. Molecular Neurodegeneration 2013 8:24.

\section{Submit your next manuscript to BioMed Central and take full advantage of:}

- Convenient online submission

- Thorough peer review

- No space constraints or color figure charges

- Immediate publication on acceptance

- Inclusion in PubMed, CAS, Scopus and Google Scholar

- Research which is freely available for redistribution 